\begin{abstract}
Arachidonic acid (AA), a fatty acid found in the human bone marrow plasma, is the precursor of eicosanoids that modulate bone marrow haematopoiesis. To further our understanding of the role of $\mathrm{AA}$ in the bone marrow physiology, we have assessed its incorporation in human bone marrow mononuclear cells. Gas chromatography analysis indicates the presence of $A A$ in their fatty acid composition. In bone marrow mononuclear cells, $\left[{ }^{3} \mathrm{H}\right]-\mathrm{AA}$ is incorporated into triglycerides and is later delivered into phospholipids, a result not observed with blood mononuclear cells. Prelabelling-chase experiments indicate a trafficking of labelled AA from phosphatidylcholine to phosphatidylethanolamine. Stimulation of prelabelled bone marrow mononuclear cells with granulocyte-macrophage colony-stimulating factor (GM-CSF) results in the release of a part of the incorporated labelled $A A$. Finally, exogenous AA ( up to $1 \mu \mathrm{M}$ ) has no significant effect on cell growth. In conclusion, human bone marrow mononuclear cells participate to the control of marrow AA concentrations by incorporating AA into phospholipids and triglycerides. In turn, bone marrow mononuclear cells can release $A A$ in response to the potent haematopoietic growth factor GM-CSF.
\end{abstract}

Key words: Arachidonic acid, GM-CSF, Mononuclear marrow cells, Proliferation

\section{Arachidonic acid and freshly isolated human bone marrow mononuclear cells}

\author{
Y. Denizot, ${ }^{\text {CA }}$ V. Desplat, C. Dulery, F. Trimoreau and \\ V. Praloran
}

Laboratoire d'Hématologie Expérimentale, Faculté de Médecine, 2 rue Dr Marcland, 87025 Limoges, France

${ }^{\mathrm{CA} C o r r e s p o n d i n g}$ Author
Tel: (+33) 0555435867
Fax: (+33) 0555435866

\section{Introduction}

Arachidonic acid (AA), a 20-carbon polyunsaturated fatty acid, is converted to prostaglandins through the cyclooxygenase pathway or to hydroxyeicosatetraenoic acid (HETE) and to leukotrienes through the lipoxygenase pathway. ${ }^{1}$ Several AA metabolites modulate human haematopoiesis by acting on the growth of human bone marrow erythroid and myeloid progenitors, ${ }^{2-5}$ and on the cytokine production by human bone marrow stromal cells. ${ }^{6}$ The role of AA in the bone marrow physiology is poorly documented. Recently we have reported the presence of AA in the human bone marrow plasma and its capture by cultured human bone marrow stromal cells. ${ }^{7}$ To further our understanding of the role of AA in the bone marrow, the uptake and the distribution of AA among triglycerides (TG) and phospholipids (PL) in human bone marrow mononuclear cells were compared with those in blood mononuclear cells and erythrocytes. We have also investigated the role of AA on the proliferation of human bone marrow mononuclear cells and their capacity to release $\mathrm{AA}$ in response to granulocyte-macrophage colony stimulating factor (GM-CSF), a potent haematopoietic growth factor.

\section{Material and Methods}

\section{Reagents}

AA (Tebu, Le Perray en Yvelines, France) was dissolved $(0.1 \mathrm{M})$ in ethanol stored at $-80^{\circ} \mathrm{C}$, and appropriately diluted in $2 \%$ human serum albumin (HSA) from Bio Merieux (France) immediately before use. Phosphatidylethanolamine (PE), phosphatidylcholine (PC), phosphatidylserine (PS), phosphatidylinositol (PI), neutral lipid (NL), bovine serum albumin (BSA) and standard solutions of monoglycerides (MG), diglycerides (DG), TG and PL were from Sigma (Saint Quentin Fallavier, France). Hanks's balanced salts solution (HBSS), RPMI 1640, penicillin, streptomycin and fetal calf serum (FCS) were from Gibco (Cergy Pontoise, France). $\left[{ }^{3} \mathrm{H}\right]$-thymidine and $\left[{ }^{3} \mathrm{H}\right]-\mathrm{AA}$ were from Amersham (Les Ulis, France). GM-CSF was from R\&D systems (Oxon, UK).

Human bone marrow cells from patients undergoing a myelogram as part of a diagnostic procedure were harvested by aspiration into heparinized tubes (Vacutainer system, Becton Dickinson, Meylan, France). When samples were considered as normal by morphological analysis of the May Grunwald Giemsa stained smears, bone marrow mononuclear cells were isolated by separation on a Ficoll gradient $(400 \times \mathbf{g}$, 
$20 \mathrm{~min})$ and washed twice with HBSS $(400 \times \mathbf{g}$, $10 \mathrm{~min}$ ) before use. For preparation of blood mononuclear cells, human blood was drawn from healthy volunteers using heparin as anticoagulant and prepared as bone marrow cells. For preparation of erythrocytes, blood was recovered using heparin as anticoagulant. The buffy coat was aspirated and discarded. The red cells were washed three times with HBSS before use.

\section{Fatty acid analysis of human bone marrow} mononuclear cells

Cell lipids were extracted from freshly isolated mononuclear bone marrow cells according to Floch $e t$ $a l .{ }^{8}$ Fatty acids were then methyl transesterified and the resulting fatty acid methyl esters were separated by gas chromatography. ${ }^{9}$ Standards were run to identify the compounds quantified by gas chromatography.

\section{Incorporation of $\left[{ }^{3} \mathrm{H}\right]-\mathrm{AA}$ in cells}

The incorporation of $\left[{ }^{3} \mathrm{H}\right]-\mathrm{AA}$ was performed with 5 $\times 10^{6}$ human bone marrow mononuclear cells, $5 \times$ $10^{6}$ blood mononuclear cells and $5 \times 10^{7}$ blood erythrocytes maintained in $1 \mathrm{ml}$ of RPMI 1640 medium without FCS. $\left[{ }^{3} \mathrm{H}\right]$-AA $(0.1 \mu \mathrm{Ci} ; 210 \mathrm{Ci} / \mathrm{mmol})$ was added into the medium for various periods of time. At the end of the experiments, cells were harvested by centrifugation $(800 \times \mathbf{g}, 10 \mathrm{~min})$ and then stored at $-20^{\circ} \mathrm{C}$ until used. For AA remodelling studies, mononuclear bone marrow cells were labelled with $\left[{ }^{3} \mathrm{H}\right]$-AA for $0.5 \mathrm{~h}$, washed with HBSS, and incubated in $1 \mathrm{ml}$ of RPMI 1640 without FCS for 2,5 and $22 \mathrm{~h}$ or used immediately.

\section{Lipid extraction}

Cells were mixed with $1 \mathrm{ml}$ of $0.1 \%$ sodium dodecyl sulphate in water, and incubated for $30 \mathrm{~min}$ at $56^{\circ} \mathrm{C}$ with $3 \mathrm{ml}$ of chloroform/methanol $(2: 1, \mathrm{v} / \mathrm{v})$. The chloroformic extract was washed with $5 \mathrm{ml}$ of $0.1 \mathrm{M}$

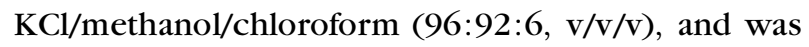
evaporated. ${ }^{10}$ The dry extract was recovered in $150 \mu 1$ of chloroform and applied to a thin layer chromatography (TLC) plate (Silica gel $60(20 \times 20 \mathrm{~cm}$, $0.25 \mathrm{~mm}$ ), Merck) and submitted to TLC. The plate was developed in the mixture of diethyl ether/ hexane/acetic acid (70:30:1, v/v/v). Each lane was divided in areas of $0.5 \mathrm{~cm}$ length which were scraped into vials and radioactivity was measured on a Packard liquid scintillation counter. Solutions of MG, DG, TG, PL and AA were used as standards and visualized with iodine vapour.

\section{Analysis of labelled PL}

For the separation of the various species of cellular PL, the corresponding areas were scraped from the TLC plates and were extracted with chloroform/ methanol $(2: 1, v / v)$. Samples were then rechromatographed using a solvent system of chloroform/ methanol/acetic acid/water (50:30:8:4, v/v/v/v). ${ }^{10}$ Each lane was divided in areas of $0.5 \mathrm{~cm}$ length and processed as above. Solutions of PC, PS, PI, and PE were used as standards and visualized with iodine vapour. In this chromatography, PI and PS migrated to the same area.

To ensure that the labelled compound in cellular PL from freshly-isolated marrow mononuclear cells was authentic AA, labelled PL were submitted to base hydrolysis. ${ }^{11}$ The labelled PL were resuspended in $1 \mathrm{ml}$ of $2 \mathrm{M} \mathrm{KOH}$ in ethanol/water $(3: 1, \mathrm{v} / \mathrm{v})$. After $40 \mathrm{~min}$ at $60^{\circ} \mathrm{C}, 1 \mathrm{ml}$ of water and $1 \mathrm{ml}$ of $6 \mathrm{~N} \mathrm{HCl}$ were added to the mixture to acidify the phase $(\mathrm{pH}$ 3). Labelled compounds were extracted with chloroform/methanol $(2: 1, \mathrm{v} / \mathrm{v})$ and rechromatographed using a solvent system of diethyl ether/hexane/acetic acid (70:30:1, v/v/v). The amount of radioactivity migrating with PL and free AA was determined by liquid scintillation counting. In another set of experiments labelled PL were hydrolysed with $\mathrm{PLA}_{2}$ from bovine pancreas (Sigma). Briefly, labelled PL samples were resuspended in $1 \mathrm{ml}$ of diethyl ether/methanol (95:5, v/v) containing $50 \mu 1$ of Tris buffer $(0.05 \mathrm{M})$, $\mathrm{CaCl}_{2}(25 \mathrm{mM})$, EDTA $(1 \mathrm{mM})$, and $1 \mathrm{mg}$ of phospholipase. The reaction mixture was incubated at $37^{\circ} \mathrm{C}$ for $2 \mathrm{~h}$ with continuous shaking. After evaporation of solvent, samples were rechromatographed as for base hydrolysis.

\section{Proliferation studies}

Freshly-isolated bone marrow mononuclear cells $(1 \times$ $10^{5}$ per well) were cultured in 96-well microtitre plates in $100 \mu 1$ of RPMI 1640 with $10 \%$ FCS in the presence of AA (from $1 \mu \mathrm{M}$ to $0.1 \mathrm{nM}$ ) or the appropriate vehicle $(10 \mu 12 \%$ HSA). After $64 \mathrm{~h}$ of incubation, cultures were pulsed for $8 \mathrm{~h}$ with $1 \mu \mathrm{Ci}$ / $\mathrm{ml}\left[{ }^{3} \mathrm{H}\right]$ thymidine and cells were harvested using a Skatron cell harvester. Each experiment was carried out as sixplicates. In separate sets of experiments, cells (in triplicate samples) were harvested and counted by using a haemocytometer. Data were compared using the Student's $t$-test for paired variables.

\section{Release of AA from $\left[{ }^{3} \mathrm{H}\right]$-labelled bone marrow mononuclear cells}

Freshly-isolated human bone marrow mononuclear cells were labelled for $0.5 \mathrm{~h}$ with $\left[{ }^{3} \mathrm{H}\right]-\mathrm{AA}$ as reported above. After washing, labelled cells $\left(1 \times 10^{6}\right)$ were 
suspended in $1 \mathrm{ml}$ of RPMI 1640 containing $0.25 \%$ fatty acid-free $\mathrm{BSA}, 1 \mathrm{mM} \mathrm{Ca}{ }^{2+}$ and $1 \mathrm{mM} \mathrm{Mg}^{2+}$. Cells were then incubated at $37^{\circ} \mathrm{C}$ in the absence or presence of GM-CSF $(100 \mathrm{ng} / \mathrm{ml})$. After various periods of time (from 1 to $60 \mathrm{~min}$ ) the mixture was centrifuged $(5 \mathrm{~min}, 2000 \times \mathrm{g})$ and the $\left[{ }^{3} \mathrm{H}\right]$-supernatant fluid was removed into a separate vial. Radioactivity in the packed labelled cells and in the radioactive supernatant fluid were then measured on a Packard liquid scintillation counter.

\section{Results}

Fatty acid composition of human bone marrow mononuclear cells

As shown in Table 1, AA is present in freshly isolated human bone marrow mononuclear cells.

\section{Incorporation of $\left[{ }^{3} \mathrm{H}\right]-\mathrm{AA}$ in cellular lipid species}

After $5 \mathrm{~h}$ of incubation with $\left[{ }^{3} \mathrm{H}\right]-\mathrm{AA}$, freshly-isolated bone marrow mononuclear cells, blood mononuclear cells and erythrocytes had incorporated $52 \%, 49 \%$ and $41 \%$ of the initially added radioactivity, respectively (mean of three experiments). Lipids were extracted from labelled cells and separated into classes by TLC. The distribution of label in cell lipids as a function of time is shown in Fig. 1. A trafficking of labelled AA from TG to PL was observed with freshly-isolated human bone marrow mononuclear cells (Fig. 1A) but not with blood mononuclear cells and erythrocytes (Fig. 1B and 1C, respectively). For mononuclear bone marrow cells at $24 \mathrm{~h}, 67 \pm 8 \%$ of the label was recovered in PL while $30 \pm 7 \%$ was recovered in TG. Less than 3\% of label was recovered in DG or as free AA. Labelled MG were not detected.

\section{Incorporation of $\left[{ }^{3} \mathrm{H}\right]-\mathrm{AA}$ in cellular $\mathrm{PL}$ species}

We next investigated the distribution of $\left[{ }^{3} \mathrm{H}\right]-\mathrm{AA}$ into PL species using mononuclear bone marrow cells

Table 1. Fatty acid composition of human bone marrow mononuclear cells. Data (mean \pm SEM of four independent samples) are reported as the percentage of fatty acid species

Major fatty acids

\section{C14:0}

C16:0

C16:1

C18:0

C18:1

C18:2

C20:4

Others*
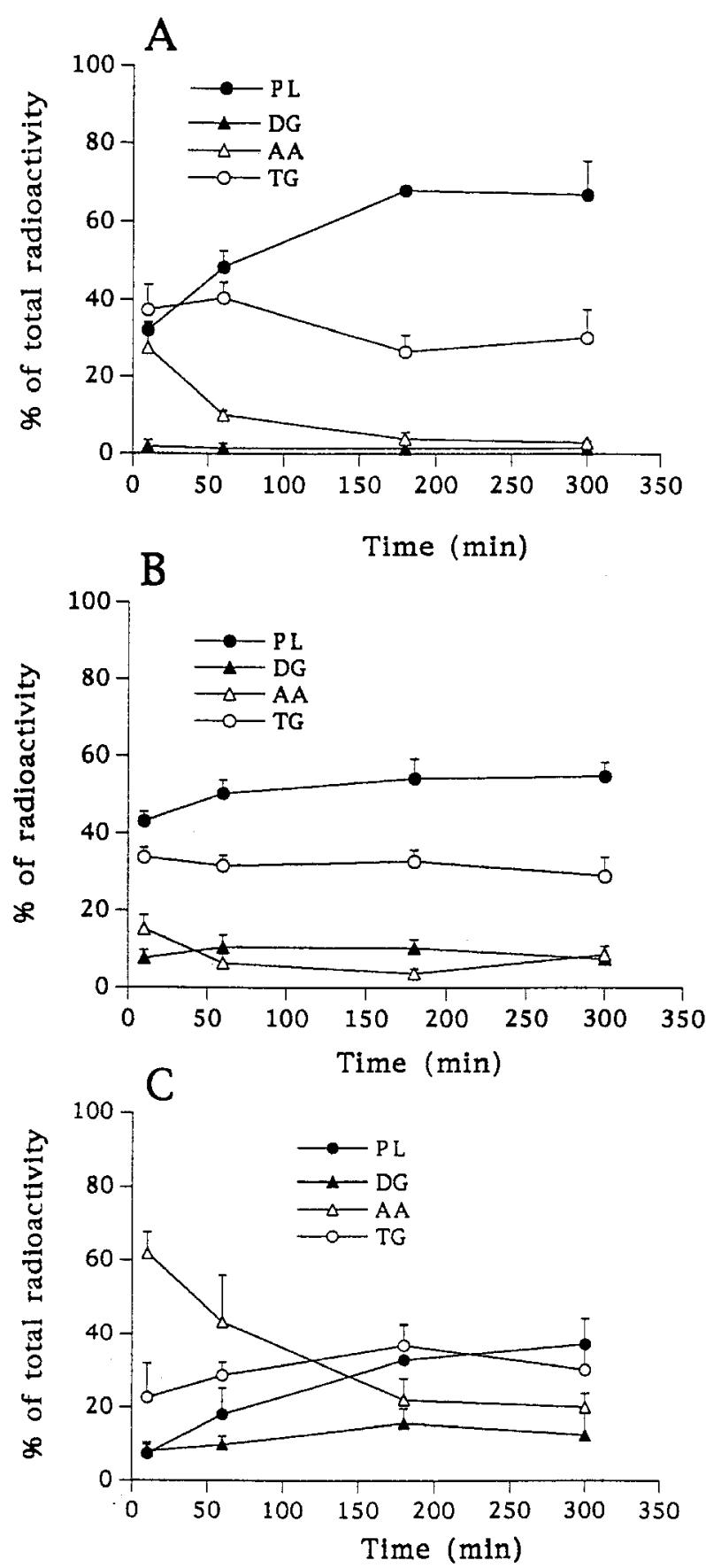

FIG. 1. Time-course of $\left[{ }^{3} \mathrm{H}\right]-\mathrm{AA}$ incorporation into bone marrow mononuclear cells $(A)$, blood mononuclear cells $(B)$ and erythrocytes (C). Cells were incubated with $\left[{ }^{3} \mathrm{H}\right]-A A$ for $10 \mathrm{~min}, 1,5$, or $24 \mathrm{~h}$. Lipids were extracted and separated as described in Methods. Results are expressed as the percentage of total radioactivity found in cells. Mean \pm SEM of three independent experiments in duplicate. PL: phospholipids; DG: diglycerides; TG: triglycerides; AA: arachidonic acid.

labelled for $0.5 \mathrm{~h}$. The percentage (mean of three experiments) of incorporated AA into PE (43.7 \pm $4.3 \%)$ was similar to that for PC $(42.0 \pm 3.6 \%)$ and higher than for PI + PS (14.1 $\pm 1.6 \%)$. We then investigated the putative exchange of labelled AA between PL species. Freshly-isolated bone marrow 


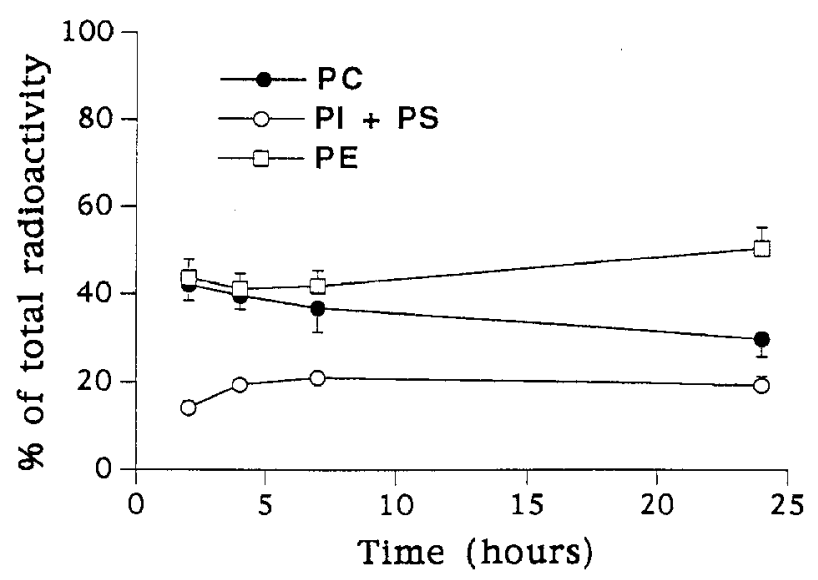

FIG.2. Trafficking of $\left[{ }^{3} \mathrm{H}\right]-A A$ into $P L$ species of bone marrow mononuclear cells. Cells were labelled for $0.5 \mathrm{~h}$ with $\left[{ }^{3} \mathrm{H}\right]-\mathrm{AA}$. Medium was removed and cells were incubated with medium free of $\left[{ }^{3} \mathrm{H}\right]-A A$ for 2,5 or $22 \mathrm{~h}$. Results are expressed as the percentage of total radioactivity found in $\mathrm{PL}$ species. Mean \pm SEM of three independent experiments in duplicate. PC: phosphatidylcholine; PE: phosphatidylethanolamine; PI + PS: phosphatidylinositol + phosphatidylserine (comigration).

mononuclear cells labelled for $0.5 \mathrm{~h}$ were grown in culture medium free of $\left[{ }^{3} \mathrm{H}\right]$-AA for 2,5 or $22 \mathrm{~h}$. Under these experimental conditions, a trafficking of $\left[{ }^{3} \mathrm{H}\right]-\mathrm{AA}$ from PC to PE was documented (Fig. 2).

Base hydrolysis of labelled PL from bone marrow mononuclear cells resulted in the loss of $99 \%$ (mean of three experiments) of radioactivity, which was recovered as free fatty acid. Similarly, treatment of

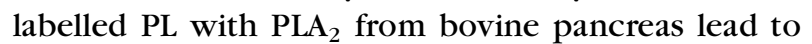
the loss of $80 \%$ (mean of two experiments) of label.

\section{Release of $\left[{ }^{3} \mathrm{H}\right]-\mathrm{AA}$ by bone marrow mononuclear cells}

Prelabelled human bone marrow mononuclear cells were challenged with GM-CSF $(100 \mathrm{ng} / \mathrm{ml})$ for various periods of time. As reported in Fig. 3, GM-CSF stimulated in a time-dependent manner $\left[{ }^{3} \mathrm{H}\right]-\mathrm{AA}$ release by human bone marrow mononuclear cells. Their amounts of $\left[{ }^{3} \mathrm{H}\right]-\mathrm{AA}$ released in response to $1 \mathrm{~h}$ of stimulation with GM-CSF represented $11.4 \pm 2.9 \%$ (mean \pm SEM of three independent experiments) of their total $\left[{ }^{3} \mathrm{H}\right]-\mathrm{AA}$ content.

\section{Effect of AA on the growth of human bone marrow mononuclear cells}

As reported in Table 2 , the addition of AA $(1 \mu \mathrm{M}$ to $1 \mathrm{nM})$ had no significant $(P>0.1)$ effect on the $\left[{ }^{3} \mathrm{H}\right]$-thymidine incorporation by freshly-isolated human bone marrow mononuclear cells cultured with $10 \%$ FCS in medium. No significant $(P=0.5$, Mann-Whitney $U$-test, three experiments) effect of AA $(1 \mu \mathrm{M})$ was found after 3 days of growth on the number of viable mononuclear marrow cells $(87.4 \pm$

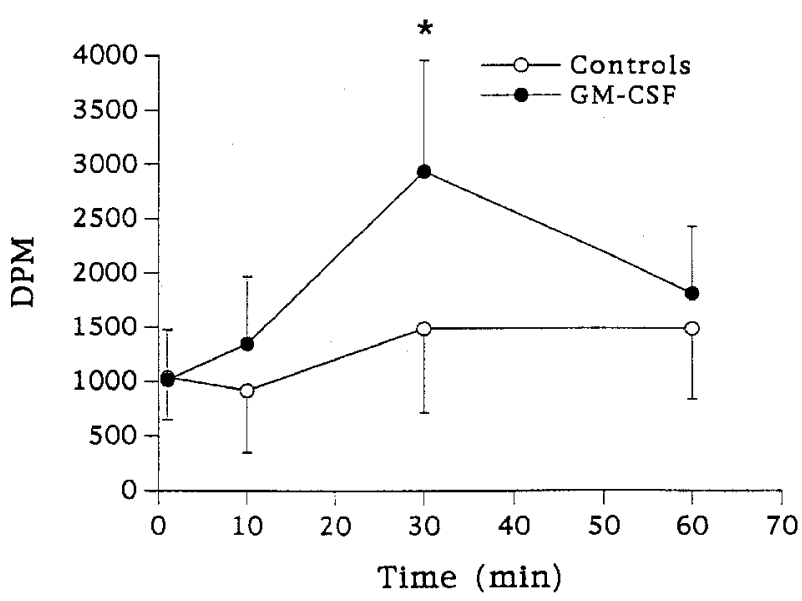

FIG. 3. Release of $\left[{ }^{3} \mathrm{H}\right]-A A$ by bone marrow mononuclear cells. Labelled cells were stimulated with GM-CSF (100 ng/ $\mathrm{ml}$ ) at $37^{\circ} \mathrm{C}$ for various periods of time. Radioactivity in cell supernatants was measured on a liquid scintillation counter. Mean \pm SEM of three independent experiments. ${ }^{*} P<0.05$ compared with controls (Mann-Whitney U-test).

$10.4 \times 10^{3}$ cells $)$ compared with controls $(88.5 \pm 13.7$ $\times 10^{3}$ cells).

\section{Discussion}

AA metabolism plays a pivotal role in many cellular functions, ${ }^{1}$ and AA metabolites act on human marrow haematopoiesis in vitro. ${ }^{2-5}$ Recently we have reported the presence of AA in the human bone marrow plasma. $^{7}$ To further our understanding of the role of AA in the human bone marrow, we have investigated the capacity of human bone marrow mononuclear cells to capture and to release $\mathrm{AA}$ as well as the putative role of AA in their growth.

Using gas chromatography analysis, we found that AA is present in freshly-isolated human bone marrow mononuclear cells. Similarly to what was observed with human bone marrow stromal cell cultures, ${ }^{7}$ experiments with $\left[{ }^{3} \mathrm{H}\right]$-AA indicate that freshly-isolated bone marrow mononuclear cells incorporate AA into PL and TG. Time-course experiments reveal a transfer of AA from TG to PL. As already shown in several inflammatory cell types, the incorporation of AA into TG is important to capture fatty acids for PL biosynthesis but also to regulate AA metabolism. ${ }^{12,13}$ In contrast to bone marrow mononuclear cells, no transfer of AA from TG to PL is observed with blood mononuclear cells. As previously reported for various kinds of mammalian erythrocytes, ${ }^{14,15}$ human erythrocytes incorporate exogenous AA into PL and TG. Their lack of transfer of AA from TG to PL might be related to their inability of de novo PL synthesis. ${ }^{12}$

The analysis of PL species of human bone marrow mononuclear cells indicates a preferential incorporation of AA into PE and PC. Similarly to what was observed in several inflammatory cell types, ${ }^{12,16}$ prelabelling-chase experiments indicate a trafficking 
of labelled AA from PC to PE. At this time the meaning of this traffic is unclear. PLA $\mathrm{PA}_{2}$-treatment and base hydrolysis experiments confirm that $\left[{ }^{3} \mathrm{H}\right]-\mathrm{AA}$ is incorporated unmodified in mononuclear bone marrow PL and is linked by an ester bond. Stimulation of prelabelled bone marrow mononuclear cells with GMCSF results in the hydrolysis of a part of the incorporated labelled AA. This effect might be mediated through the activation of a cellular phospholipase $\mathrm{A}_{2}\left(\mathrm{PLA}_{2}\right)$ activity. Strenghtening this hypothesis GMCSF generates $\mathrm{PLA}_{2}$ activity with the release of free fatty acids from neutrophil plasma membranes. ${ }^{17}$

\section{Exogenous}

AA does not change the growth of human bone marrow mononuclear cells assessed by $\left[{ }^{3} \mathrm{H}\right]$-thymidine incorporation into DNA and cell counts. In similar experimental conditions several lipoxygenase metabolites of AA have no effect on their growth. ${ }^{18}$ As a positive control of cell stimulation we may mention that in similar experimental conditions, the lipid mediator platelet-activating factor (PAF) stimulates their $\left[{ }^{3} \mathrm{H}\right]$-thymidine incorporation. ${ }^{19}$

In conclusion human bone marrow mononuclear cells might participate to the control of marrow AA concentrations by incorporating AA into their PL and TG. In turn, the potent haematopoietic growth factor GM-CSF stimulates their AA release, a result of importance considering the role of eicosanoids during human marrow haematopoiesis. ${ }^{2}$

\section{References}

1. Sigal E. The molecular biology of mammalian arachidonic acid metabolism. Am J Physiol 1991; 260: L13-L28.

2. Dupuis F, Desplat V, Praloran V, Denizot Y. Effects of lipidic mediators on the growth of human myeloid and erythroid marrow progenitors. J Lipid Mediators Cell Signalling 1997; 16: 117-125.

3. Rossi GB, Migliaccio AR, Migliaccio G, Lettieri F, Di Rosa M, Mastroberardino $\mathrm{G}$, Peschle $\mathrm{C}$. In vitro interactions of $\mathrm{PGE}$ and cAMP with murine and human erythroid precursors. Blood 1980; 56: 74-79.

4. Lu L, Broxmeyer HE. Comparative influence of phytohemagglutininstimulated leukocyte conditioned medium, hemin, prostaglandin E, and low oxygen tension on colony formation by erythroid progenitor cells in normal human bone marrow. Exp Hematol 1985; 13: 989-993.

5. Stenke L, Mansour M, Reizenstein P, Lindgren JA. Stimulation of human myelopoiesis by leukotrienes $\mathrm{B} 4$ and $\mathrm{C} 4$ : interactions with granulocytemacrophage colony-stimulating factor. Blood 1993; 81: 352-356.

6. Denizot Y, Trimoreau F, Praloran V. Effects of lipid mediators on the synthesis of leukemia inhibitory factor and interleukin- 6 by human bone marrow stromal cells. Cytokine 1998; 10: 781-785.

7. Denizot Y, Dulery C, Trimoreau F, Desplat V, Praloran V. Arachidonic acid and human bone marrow stromal cells. Biochim Biophys Acta 1998; 1402: 209-215.

8. Floch JM, Lees M, Sloane GH. A simple method for isolation and purification of total lipids from animal tissues. J Biol Chem 1957; 226: 497-509.

9. Maclouf J, Rigaud M, Durand J, Chebroux P. Gas capillary columns applied to prostaglandins measurement: a useful tool for gas-chromatography mass spectrometry analysis. Prostaglandins 1976; 11: 999-1017.

10. Denizot Y, Najid A, Rigaud M. Incorporation of arachidonic acid in a human cancer gastric tumor cell line (HGT) at various stages of cell proliferation. Cancer Lett 1993; 68: 199-205.

11. Triggiani M, Oriente A, Marone G. Differential roles for triglyceride and phospholipid pools of arachidonic acid in human lung macrophages. $J$ Immunol 1994; 152: 1394-1403.

12. MacDonald JIS, Sprecher H. Phospholipid fatty acid remodeling in mammalian cells. Biochim Biophys Acta 1991; 1084: 105-121.

13. Triggiani M, Oriente A, de Crescenzo G, Rossi G, Marone G. Biochemical functions of a pool of arachidonic acid associated with triglycerides in human inflammatory cells. Int Arch Allergy Immunol 1995; 107: 261-263.

14. Kobayashi T, Levine L. Arachidonic acid metabolism by erythrocytes. $J$ Biol Chem 1983; 258: 9116-9121.

15. Kaya K, Miura T, Kubota K. Different incorporation rates of arachidonic acid into alkenylacyl-, alkylacyl- and diacylphosphatidyl-ethanolamine of rat erythrocytes. Biochim Biophys Acta 1984; 796: 304-311.

16. Fonteh A, Chilton FH. Rapid remodeling of arachidonate from phosphatidylcholine to phosphatidylethanolamine pools during mast cell activation. J Immunol 1992; 148: 1784-1791.

17. DellaPuca R, Gallicchio VS. The regulation of phospholipase-A2 (PLA-2) by cytokines expressing hematopoietic growth-stimulating properties. Proc Soc Exp Biol Med 1996; 212: 174-184.

18. Desplat V, Dupuis F, Trimoreau F, Dulery C, Praloran V, Denizot Y. Effects of lipoxygenase metabolites of arachidonic acid on the growth of human mononuclear marrow cells and marrow stromal cell cultures. Med Inflamm 1998; 7: 31-33.

19. Denizot Y, Dupuis F, Trimoreau F, Verger C, Allegraud A, Praloran V. PAF and haematopoiesis. IX. Platelet-activating factor increases DNA synthesis in human bone marrow cells. J Lipid Mediators Cell Signalling 1996; 15: $1-4$.

ACKNOWLEDGEMENTS. We are grateful to the 'Ligue Nationale Contre le Cancer' (Comité de la Corrèze et de la Creuse) and to the 'Conseil Régional du Limousin' for funding our project. V.D. is supported by a grant from the 'Ligue Nationale Contre le Cancer' (Comité de la Corrèze). We thank M. Rigaud and A. Soustre for gas chromatography experiments. This paper is the sixth of a series: Arachidonic acid metabolites and haematopoiesis.

\section{Received 30 November 1998; accepted 11 December 1998}




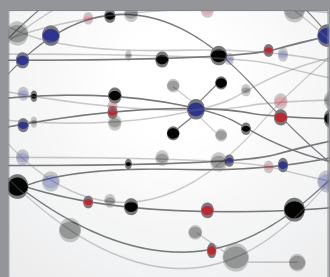

The Scientific World Journal
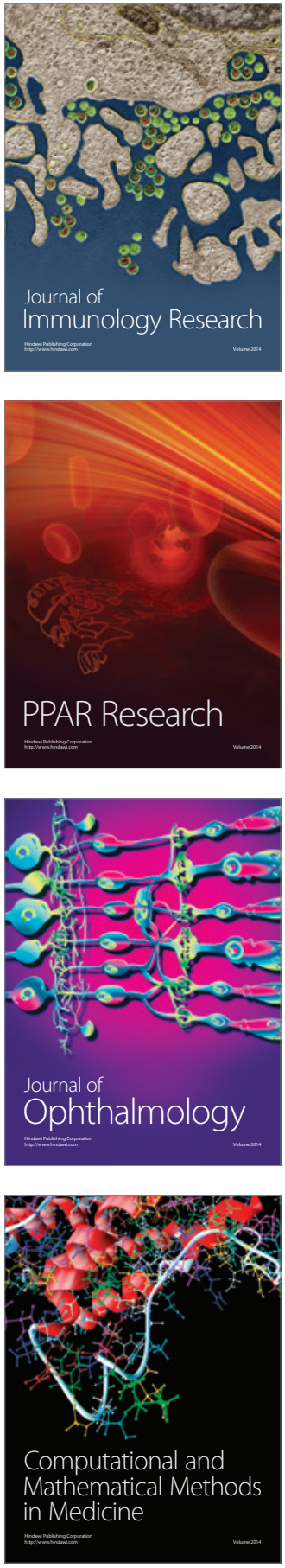

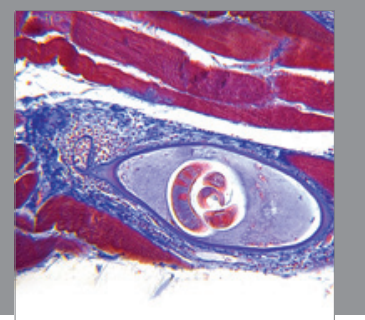

Gastroenterology

Research and Practice
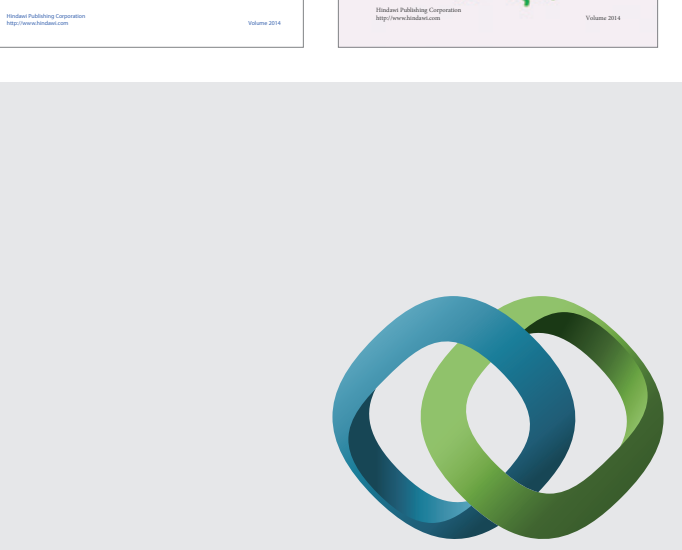

\section{Hindawi}

Submit your manuscripts at

http://www.hindawi.com
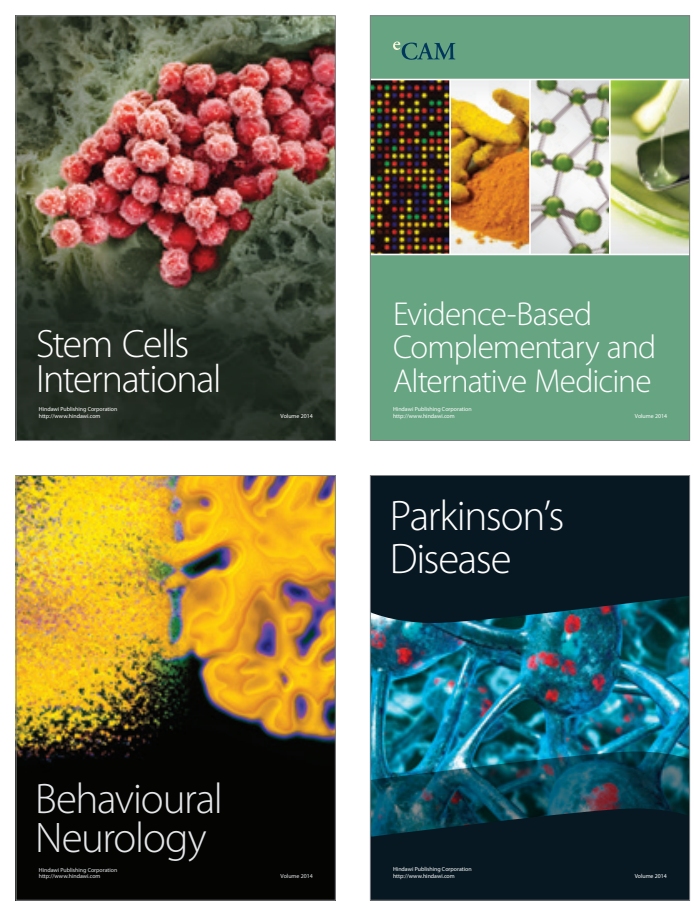

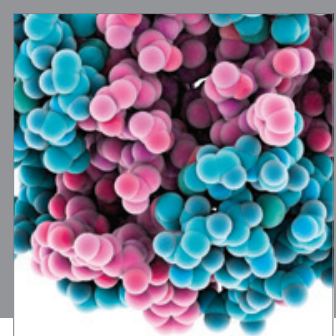

Journal of
Diabetes Research

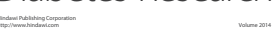

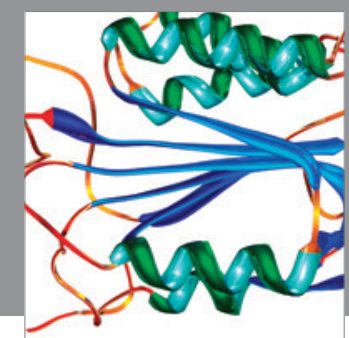

Disease Markers
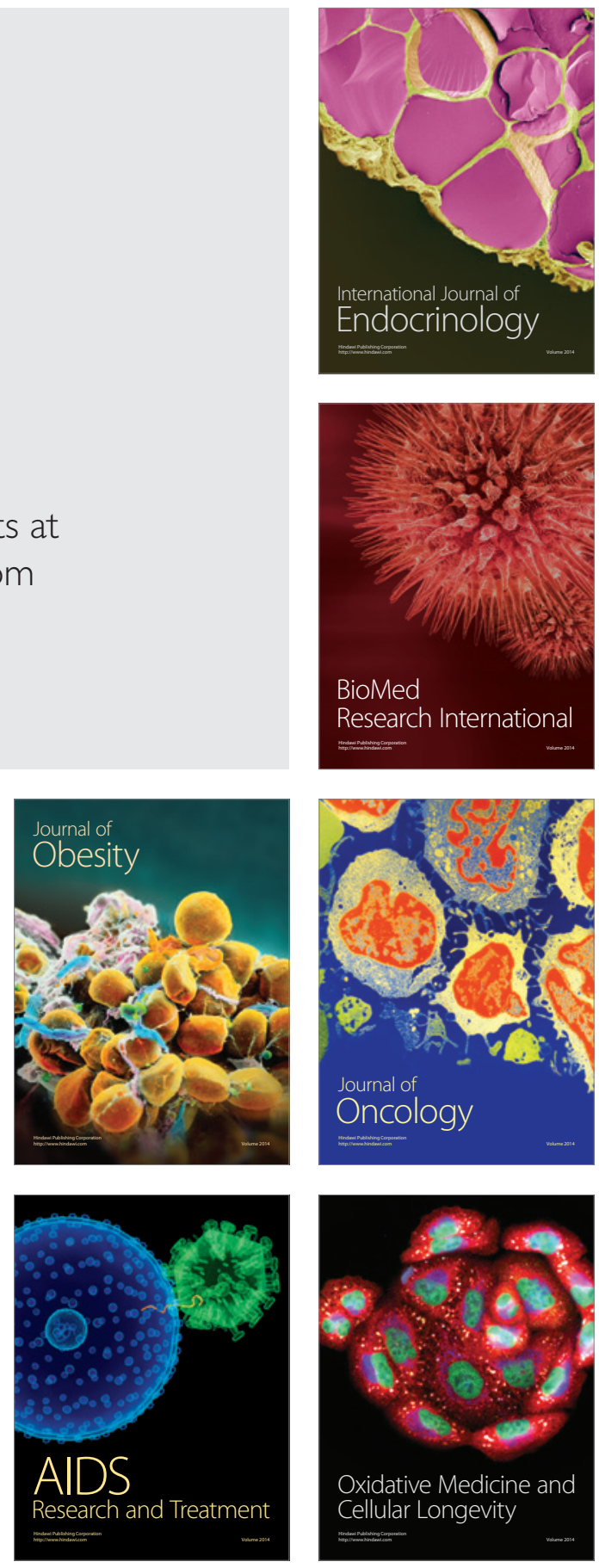